\title{
The Relationship Between SMEs and Insurance providers in Nelson Mandela Metropolitan Area, South Africa
}

\author{
Kudakwashe Chodokufa \\ Department of Business Management, University of South Africa, Preller Street, Muckleneuk \\ Ridge, City of Tshwane,P.O. Box 392, UNISA,0003, South Africa \\ Email: chodok@unisa.ac.za \\ Norman Chiliya \\ School of Economics and Business, University of Witwatersrand \\ Private Bag 3, Wits, 2050 \\ Email: Norman.chiliya@wits.ac.za
}

\section{Doi:10.5901/mjss.2014.v5n14p84}

\begin{abstract}
Media reports on the effects of climate change on Small Medium Enterprises (SMEs) in South Africa has increased over the past decade. The amount of loss in terms of assets and infrastructure suffered by SMEs is disturbing. Yet insurance providers are not eager to insure SMEs and prefer to deal larger organisations. An empirical study of 203 SMEs was done, structured questionnaires were administered to SME owners. Data was analysed and the results illustrated factors such as the reliability of an insurer, staff knowledge and brand name of the insurer have a great impact on the decision made by SMEs to build a relationship with insurance providers. The respondents, who had been approached by an insurance broker and received training, had a business relationship with an insurance provider. This helps to reach the conclusion that any form of interaction between SMEs and insurance providers helps to facilitate a business relationship.
\end{abstract}

Keywords: SMEs, Insurance and Business Relationship

\section{Introduction}

Being in business in today's tough economic environment is hard work, with the small business owner having to keep a close eye on many parts of the business, from marketing to compliance issues up to cash flow. Now they have to worry about the adverse consequences on their small business brought about by natural disasters. There many media reports that have been given on how small businesses have been affected by climate change around South Africa, yet there little or no research that has been carried out in this area. Reference to media reports from 2006 till 2012 have given an indication of this rising crisis faced by Small and Medium Enterprises (SMEs). In 2006, flood damage to small businesses and residential premises in the Nelson Mandela Metropolitan Area was estimated at R120million (SABC News 2006). The South African Coast Chamber of Commerce and Industry report that several businesses along Marine Drive in Durban were flooded and forced to closed down (IOL 2008). In 2009, Cape Town was affected by floods and a famous River Club in Observatory was flooded (SABC News 2009). In 2012, damage resulting from floods in the Eastern Cape was estimated to be more than R1 billion and this does not include the economic lasses that the province faced (Macgregor 2012). It is the SMEs that were affected the most by these realities.

SMEs owners would like to achieve growth and sustainability in their business. In order for them to achieve growth, they should guard themselves against setbacks that may hinder their progress. These setbacks may include, unexpected occurrences of theft, breakages, fires, floods, strikes, the death of the owner of the business and any other crises that may befall their business (Manning 2004).

Crisis is an inevitable part of business today and business people cannot set it apart from regular business activity (Dumaine 1993: 123-127; Mitroff 2000; Smits \&Ezzat 2003; Elsubbaugh et al 2004: 112). Friedrich and Isaacs (2006), state that an estimated $80 \%$ of small businesses in South Africa fail within the first five years of operation. The estimated rate of failure increases dramatically following a fire or any other major event such as floods and significant storm damage. The business person has to manage the rebuilding, the sourcing and replacement of the plant and equipment, as well as to re-supply of stock on hand (Manning 2004:6). 
SMEs play an important role as employers and in the economic growth of the modern society (Taymaz 2005; Van der Nest 2004:39; Gregory, Harvive \& Lee 2002:3). Bennett (2008:357) consented to this notion in a seminal paper by arguing that small businesses account for $99 \%$ of providers in developed countries. SMEs are a means by which governments all around the world use to improve their economies. The creation of small businesses is necessary for economic development. The same is true for South African SMEs as they are a way of redistributing wealth and restructuring society at a time the gap between the rich and poor is widening in South Africa (Hisrich, Peters \& Shepard 2005:15; Floyd \& McManus 2005:144).

There is a lot of national support that is given to SMEs by the South African government and other service providers such as insurance providers are yet to play their part in supporting this sector. This research aims to highlight through quantitative research, the nature of the relationship between SMEs and insurance providers and the factors that affect this relationship. The research was done by means of a questionnaire administered to SME managers/owners. The data was analysed and the results, conclusion and recommendations will be presented in this article.

\section{Research Problem Investigated}

Longenecker, Moore and Petty (2003:612) state that short term insurance providers are not eager to insure SMEs and may even turn them down in some cases. The same view is shared by Mthimkhulu (2008: 10), when he stated that the insurance industry prefers to deal only with established businesses. This means that an owner of a small enterprise would have to take time to educate themselves on the available products being offered by insurance providers for SMEs. Risk management is generally not something that requires immediate attention until something happens (Moore, Petty, Palich and Longenecker 2008:559). A prudent small business owner should take the time to identify the different types of risks faced by the small enterprise and find ways to mitigate them.

In most cases, SME owners do not have the skill and time to look into risk management for their business. When a disaster occurs most businesses are unable to recover because there will be no or inadequate insurance cover to protect the business. The owner could be forced to close down their business and their employees lose their source of employment. It is therefore, important to understand the nature of the relationship between insurance providers and SMEs. A review of literature has shown that insurance providers are not willing to insure SMEs and this is the problem to be investigated. The aim of this research is to investigate whether there is a business relationship between SMEs and insurance providers and to establish the nature of the relationship.

The review of literature has shown that there is no standard definition of SMEs that everyone agrees upon, but within the definition of SMEs, many authors typically define SMEs on the basis of either annual turnover or number of employees (Robinson and Pearce 1984:80; Keats and Bracker 1988:41; SBA 2004; European Commission 2003). This research will be using the definition that is provided by the South African National Small Business Act of 1996, which is summarised in the Table 1.

Table 1: SMEs Definition

\begin{tabular}{|c|c|c|}
\hline Size of the business & Turnover & Employees \\
\hline Small & Less than R2 million to R25 million & 5 to 20 \\
\hline Medium & Less than R4 million to R50 million & 20 to 200 \\
\hline
\end{tabular}

Source: KNC \& Associates (2002:3).

The South African SMEs sector has been neglected during much of the twentieth century following the discovery of diamonds and gold and the establishment of a modern, capitalist economy with almost exclusive control (Ministry of Trade and Industry, 1994:9). Currently the unemployment rate is reported to be at 24, 9 percent (Statistic South Africa 2013), the SMEs sector has a major role to play in the South African economy in terms of employment creation and income generation.

SMEs employ approximately nine million South Africans and they contribute more than $60 \%$ of the national South African GDP (Mahembe 2011; Finweek 2012). They are the vehicle by which the lowest income people in our society gain access to economic opportunities at a time that distribution of income and wealth in South Africa is amongst the most unequal in the world. However, the South African government has since identified the SMEs sector as a priority in creating jobs to solve the high unemployment condition (Rwigema and Venter 2004:396; SEDA 2007). 
Government cannot be able to achieve its goal unless other service providers give support to the SMEs industry. The main problem experienced by owners or operators of SMEs, is the difficulty in accessing the necessary support from service providers. Thus, it is imperative that significant investment (in terms of support from service providers) is made in SMEs in order to create both short term and long-term capacity for labour absorption, as well as to improve the income generation and redistribution.

The success of the SMEs sector can be aided if a relationship between SMEs and other service providers such as insurance providers is established. In the event that an SME faces a catastrophe like a fire, strike or that its employees are injured at work, they need to have insurance to cover such eventualities as such disasters may leave them vulnerable if they do not have insurance. The occurrence of natural disasters in most cases results in the loss of workers, along with key talent and organisational knowledge, from low morale, fear, physical relocation or death. The owners of SMEs need to develop recovery plans. These strategies should address the safety, health and welfare of employees before, during and after an emergency. Crisis preparedness, response and recovery are essential to help businesses begin to recover (Manning 2004). This shows the importance of having an insurance cover in order for the business to recover from any disturbance.

The review of the theory showed that there was little or no research undertaken on SMEs and insurance, with past research predominately concentrating on large organizations. Research by Pretty (cited by Strutt 1998: 8), examined the purchase of insurance by large corporations and the benefit of the insurance program in the event of a large insurable event. The research found that as corporations increased the diversity of their products and their geographical spread of assets, they placed greater reliance on natural operating hedging, rather than transferring the risk to an insurer. This willingness to accept more of the risk themselves was found to be based on the level of diversification rather than on the actual size of the firm. The limitation of the research was that it concentrated solely on the large firms and its relevance to SMEs was not addressed (Strutt 1998: 10).

Research has been conducted into the business protection market. The aim was to look into what the level of insurance businesses hold, what types of insurance they believe are important and what insurable risk would have the largest impact on their business, should it occur. The findings from the research highlighted the need for protection whatever type of business (Manning 2004).

The culture of risk aversion constrains the growth of the SME sector among low-income entrepreneurs (Aliber 2002:4; OECD 2010:7). Micro insurance is one of the ways that he identified to encourage a positive attitude towards risk aversion. Insurance provides a hedge against risk, yet insurance that might specifically assist SMEs is rear. The only way that insurance that is specifically target at SMEs, short term insurance providers should approach SMEs and establish their needs. This can be done through establishing a business relationship.

Business relationships are valuable long-term assets of a company. It is necessary to invest in such relationships and to manage this investment to ensure their repeat business (Claro 2004). There is a need for a business relationship between SMEs and insurance providers, as a relationship of that nature can be beneficial for both parties involved. In business-to-business relationships, firms usually customise products and services more than in business to customer relationships (Claro 2004). For that reason, prices are seldom standardised, and calculated for each customer individually. In this case, Ryals (2006: 101-113), recommends the value based pricing model. This means that the price a service provider charges a customer should reflect the value a customer sees the product or services that they get. As a precondition, a company needs deep insight into and detailed knowledge of the perceived value of each customer. The success of a business relationship lies in the development and the growth of trust and commitment amongst partners (Brink and Berndt 2004:30). If there is a relationship that is created between short term insurance providers and SMEs, it will be easier for short term insurance providers to establish the insurance needs of SMEs.

Short term insurance is defined in the short- term insurance Act as providing benefits under short term policies which means engineering policies, guarantee policies, liability policies, miscellaneous policies, motor policies, accident and health policies, property policies or transportation policies or a contract comprising a combination of these policies (Short-Term Insurance Act 1998).

Households and businesses buy insurance to transfer risk from themselves to the insurance company. The insurance company accepts the risk in return for a series of payments, called premiums. In the insurance industry, underwriting is the process used by insurance providers to determine whom to insure and what to charge. During a typical year, insurance providers collect more in premiums than they pay in claims. Insurance providers are a major source of short and long term financing for businesses (Boone and Kurtz 2003:561).

Insurance providers may be a good source of funds for SMEs especially those involved in real estate ventures. The business owner can go directly to the insurance company or contact its agent or a mortgage banker. While insurance providers have traditionally engaged in debt financing, they have more recently demanded that they be permitted to buy 
an equity share in the business as part of the total package (Megginson et al. 1997:12). This means that they become partners and relationship building between the two becomes an essential element.

The concept of relationship building emanates from the theory of relationship marketing. Boone and Kurtz (2003:409) define relationship building as developing and maintaining long term, cost effective exchange relationships with individual customers, suppliers, employees, and other partners for mutual benefit. Relationship building involves the whole organisation and its stakeholders. Trust is a major component of the relationship building process. The term relationship refers to voluntary repeat business between a supplier and a customer where the behaviour is planned, cooperative, intended to continue or mutual benefit and is perceived by both parties as a relationship. Using this approach means that repeat purchase through lack of alternative suppliers or the operation of loyalty schemes cannot be defined as relationship marketing (Little and Marandi 2003:23). An ongoing interaction between insurance providers and SMEs means that there will be an improvement on the services that will be provided to SMEs.

\section{Research Objectives}

\subsection{Main Objective}

The main objective of the research was to determine which factors have the most influence on relationship building between SMEs and Insurance providers.

\subsection{Secondary Objective}

To investigate if having an insurance policy and having been approached by an insurance broker has an effect on the establishment of a business relationship between SMEs and insurance providers.

\section{Hypotheses}

\subsection{Primary Hypothesis}

$\mathrm{H}_{0}$ : The level of training in the field of short term insurance and the factors influencing the purchase of insurance by SME managers or owners has no effect on their relationship with insurance brokers;

$\mathrm{H}_{1}$ : The level of training in the field of short term insurance and the factors influencing the purchase of insurance by SME managers or owners has an effect on their relationship with insurance brokers;

\subsection{Secondary Hypothesis}

$\mathrm{H}_{0}$ : SMEs who have an insurance policy and have been approached by insurance broker do not have a business relationship with insurance providers;

$\mathrm{H}_{2}$ : SMEs who have an insurance policy and have been approached by insurance broker have a business relationship with insurance providers.

\section{Methodology}

An empirical research was carried out, using a questionnaire which was administered to owners or managers of SMEs in the Nelson Mandela Metropolitan area. Data was collected through a survey type structured questionnaire that was developed, pretested and validated. The questionnaire was administered to the owners or managers of SMEs in the Nelson Mandela Metropolitan Area. The target population for the research was business owners within the Nelson Mandela Metropolitan Area. They form part of the complete group of specific population elements relevant to the research project. A sampling frame was drawn from the population and from that the actual sample was derived. The population and the sample for this study is illustrated in Figure 1. 
Figure 1: Target population, sample units, sample elements and actual sample size for the study.

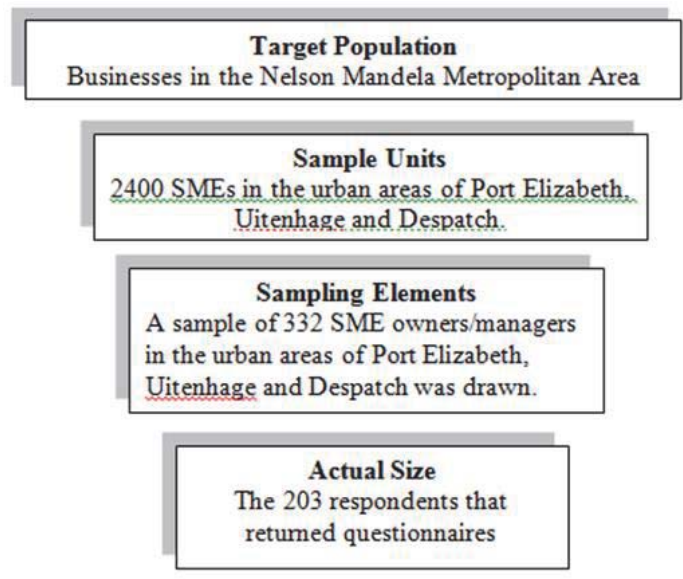

(Researcher's own construction)

\subsection{Sampling technique}

The sampling technique that was used was cluster sampling. It was most suitable for because there was heterogeneity between subgroups and homogeneity within subgroups. The SMEs were divided into clusters according to the number of employees as this is consistent with the definition of SMEs which was used for this research. The different clusters had SMEs that had the same number of employees as one cluster, one cluster contained small businesses and the other had medium sized businesses as illustrated:

\begin{tabular}{|c|c|}
\hline Type of Business & Employees \\
\hline Small & 5 to 20 \\
\hline Medium & 20 to 200 \\
\hline
\end{tabular}

Source: Adapted from Zaayman (2003:16).

\subsection{Sample size}

The level of sampling error one is willing to accept in a research influences the sample size. In reality the sample statistic is known but the population statistic is unknown, so, the difference between the sample and the population value can be assessed in terms of the likelihood that a sample value differs by a certain value from the population value (Leedy 2005:35). Cooper and Schindler (2003:190), recommend that since researchers can never be $100 \%$ certain that a sample reflects its population; they must decide how much precision they need and in making this decision.

It was estimated that there were approximately 2400 registered SMEs in the Nelson Mandela Metropolitan Area. The sample size was then calculated using $95 \%$ confidence interval with a margin of error of $5 \%$, the sample size was 332 SMEs. There were only 203 respondents who gave back their questionnaires, which represents a $61 \%$ response rate.

The data instrument used to collect data was in the form of a self administered questionnaire distributed to SMEs in the Nelson Mandela Metropolitan Area. The instrument was validated and reliability was tested using Chi-square test and Cronbach's alpha. The Chi-square test was used to test if a sample of data came from a population with a specific distribution. The data was analysed by using Statistica and Statistical Package for the Social Sciences (SPSS). The statistical method which was used to analyse the data is descriptive statistics, Cronbach's alpha, correlations, simple regression analysis and multiple regression analysis. 


\section{Research Results}

The statistical analysis conducted illustrate the extent to which the results yielded answers to the research objectives that underpin the research conducted. The main objective of the research was to determine which factors had the most influence on relationship building between SMEs and Insurance providers. To achieve this objective a questionnaire was administered to SME owners or managers, the following is a profile of the respondents in Table 3 and the size of the business in Table 4.

\subsection{Biography of respondents}

Table 3: Size Of The Businesses That Participated

\begin{tabular}{|c|l|c|c|}
\hline \multicolumn{2}{|l|}{ Size of business } & Frequency & Valid percent \\
\hline \multirow{3}{*}{} & Small & 132 & 65 \\
\cline { 2 - 4 } & Medium & 71 & 35 \\
\cline { 2 - 4 } & Total & 203 & 100.0 \\
\hline
\end{tabular}

The majority (65\%) of the respondents were small businesses and a few of the respondents (35\%) medium sized businesses who participated in the research.

Table 4: Occupation Of The Participants

\begin{tabular}{|l|c|c|}
\hline \multicolumn{1}{|c|}{ Occupation } & Frequency & Percent \\
\hline Owner & 82 & 40.4 \\
\hline Partner & 11 & 5.4 \\
\hline Middle Management & 36 & 17.7 \\
\hline Supervisor & 53 & 26.1 \\
\hline Other Total & 21 & 10.3 \\
\hline \multicolumn{2}{|c|}{203} & 100.0 \\
\hline
\end{tabular}

The majority of the respondents were owners of SMEs (40.4\%), followed by supervisors (26.1\%), middle management (17.7\%) and lastly partners (5.4\%). This affirms studies carried out by Mutezo (2005: 81) on SMEs in Tshwane where $86 \%$ of the respondents were owners of the business. This shows that most SMEs are managed by their owners.

\subsection{Descriptive Statistics}

The descriptive statistics that are provided help to explain the different variables that were used for the hypothesis testing and to help achieve the research objectives for this study.

Table 5: Descriptive Statistics On Insurance Training

\begin{tabular}{|l|c|c|}
\hline \multicolumn{1}{|c|}{ Occupation } & Yes (\%) & No (\%) \\
\hline Insurance related training & 16.7 & 83.3 \\
\hline SMEs owner/managers who want insurance training & 72.1 & 27.9 \\
\hline SMEs who have been approached by insurance brokers & 66 & 34 \\
\hline
\end{tabular}

A large number of the respondents (83.3\%) had not received any form of insurance related training and only $16.7 \%$ of the respondents received insurance training. The study shows that, $72.1 \%$ of the respondents want to be trained on short term insurance related matters and $27.9 \%$ do not want any training. Sixty six percent of the SME managers/owners who participated in the research had been approached by an insurance broker within the past six months and $34 \%$ had not been approached. These variables were used to establish the existence of a relationship between SMEs and insurance providers. 


\subsection{Hypothesis Testing}

Researchers must demonstrate instruments are reliable since without reliability, results are not replicable. Reliability analysis can be used to measure the consistency of a questionnaire. Cronbach's alpha is the most common form of internal consistency reliability coefficient. Cronbach's alpha (a) indicates the overall reliability of a questionnaire and values around 0.8 and 0.7 are good for ability tests (Field 2009:675). The following is a table summarising the results of the reliability tests done on the two hypothesis tested for this research.

\subsection{Reliability tests}

Table 6: Cronbach's alpha (a) Hypothesis

\begin{tabular}{|l|l|l|}
\hline 0.698 & $\mathrm{H}_{1}$ & $\begin{array}{l}\text { The level of training in the field of short term insurance and the factors influencing the purchase of } \\
\text { insurance by SME managers or owners has an effect on their relationship with insurance brokers; }\end{array}$ \\
\hline 0.802 & $\mathrm{H}_{2}$ & $\begin{array}{l}\text { SMEs who have an insurance policy and have been approached by insurance broker have a business } \\
\text { relationship with insurance providers. }\end{array}$ \\
\hline
\end{tabular}

\subsection{Primary Hypothesis}

H0: The level of training in the field of short term insurance and the factors influencing the purchase of insurance by SME managers or owners has no effect on their relationship with insurance brokers;

$\mathrm{H1}$ : The level of training in the field of short term insurance and the factors influencing the purchase of insurance by SME managers or owners has an effect on their relationship with insurance brokers;

Having training, the factors influencing the purchase of an insurance policy and having a business-to-business relationship, all had high reliabilities, all Cronbach's $a=.7$. A multiple regression analysis 1 as well as, Analysis of variance (ANOVA) were employed to test statistically, the significance of the null hypothesis.

Table 7: Multiple Regression Model For The Effect Of Insurance Training And Factors Influencing The Purchase Of Insurance On Business-To-Business Relationship

\begin{tabular}{|c|c|c|c|c|}
\hline \multicolumn{5}{|c|}{} \\
\hline Model & $\mathrm{R}$ & R Square & Adjusted R Square & Std. Error of the Estimate \\
\hline 1 & $.309^{\mathrm{a}}$ & .095 & .089 & .385 \\
\hline 2 & $.554^{\mathrm{b}}$ & .307 & .260 & .347 \\
\hline
\end{tabular}

The value of $\mathrm{R}^{2}$ in Model one is .095 , which shows that insurance training account for $9.5 \%$ of the variation in SMEs business-to-business relationship with insurance providers. Model two which regresses the factors influencing the purchase of insurance policy by SMEs and their business-to-business relationship has $\mathrm{R}^{2}=.307$, which means that these factors account for $30.7 \%$ of the variation in SMEs business-to-business relationship. ${ }^{2}$ The next table of analysis is the ANOVA.

\footnotetext{
${ }^{1}$ Multiple regression, is a technique employed to account for (predict) the variance in a dependent variable. It can establish that a set of independent variables explains a proportion of the variance in a dependent variable at a significant level (Garson, 2009).

${ }^{2}$ The correlation coefficient squared (known as the coefficient of determination $R^{2}$, is a measure of the amount of variability in one variable that is shared by the other. $R^{2}$ is used to show how much of this variability is shared by predictors (Field 2009:173).

${ }^{2}$ The correlation coefficient squared (known as the coefficient of determination $R^{2}$, is a measure of the amount of variability in one variable that is shared by the other. $R^{2}$ is used to show how much of this variability is shared by predictors (Field 2009:173).
} 
Table 8: Anova Results Showing The Effect Of Insurance Training And The Factors Influencing The Purchase Of Insurance On Business-To-Business Relationship

\begin{tabular}{|l|c|c|c|c|c|c|}
\hline \multicolumn{2}{|c|}{ Model } & Sum of Squares & Df & Mean Square & F & Sig. \\
\hline \multirow{3}{*}{1} & Regression & 2.201 & 1 & 2.201 & 14.839 & $.000^{\mathrm{a}}$ \\
\cline { 2 - 7 } & Residual & 20.917 & 141 & .148 & & \\
\cline { 2 - 7 } & Total & 23.119 & 142 & & & $.000^{\mathrm{b}}$ \\
\hline & Regression & 7.097 & 9 & .789 & 6.546 & \\
\cline { 2 - 6 } 2 & Residual & 16.022 & 133 & .120 & & \\
\cline { 2 - 6 } & Total & 23.119 & 142 & & & \\
\hline
\end{tabular}

ANOVA aims to show whether the model, overall, results in a significantly good degree of prediction of the outcome variable (Field, 2009:208). When tested at 95\% confidence interval and 5\% margin of error, the results reported that training and the factors influencing the purchase of insurance have a significant effect on the business-to-business relationship between SMEs and insurance providers. This can be seen from a p-value of .000 in table 6, which indicates significance of the model.

Table 9: Multiple Regression Analysis For The Effect Of Insurance Training And Factors Influencing The Purchase Of Insurance On Business-To-Business Relationship

\begin{tabular}{|c|c|c|c|c|c|c|}
\hline \multicolumn{7}{|c|}{ Coefficients $^{a}$} \\
\hline & \multirow{2}{*}{ Model } & \multicolumn{2}{|c|}{ Unstandardized Coefficients } & \multirow{2}{*}{$\begin{array}{c}\text { Standardized Coefficients } \\
\text { Beta }\end{array}$} & \multirow{2}{*}{$\mathrm{t}$} & \multirow{2}{*}{ Sig. } \\
\hline & & B & Std. Error & & & \\
\hline \multirow{2}{*}{1} & (Constant) & .595 & .161 & & 3.691 & .000 \\
\hline & Insurance training & .401 & .104 & .309 & 3.852 & .000 \\
\hline \multirow{10}{*}{2} & (Constant) & 1.780 & .540 & & 3.296 & .001 \\
\hline & Insurance training & .343 & .107 & .264 & 3.211 & .002 \\
\hline & Brand Of Insurer & -.197 & .065 & -.244 & -3.055 & .003 \\
\hline & Affordability & -.233 & .073 & -.267 & -3.179 & .002 \\
\hline & Advantages & -.124 & .054 & -.191 & -2.293 & .023 \\
\hline & Disadvantages & .064 & .050 & .106 & 1.283 & .202 \\
\hline & Durability & .039 & .045 & .069 & .870 & .386 \\
\hline & Cost & .035 & .099 & .028 & .355 & .723 \\
\hline & After Sales Care & .024 & .031 & .064 & .777 & .439 \\
\hline & Type of Policy & -.014 & .086 & -.013 & -.166 & .869 \\
\hline
\end{tabular}

It was further observed that the factors that influenced the purchase of insurance such as the brand name of insurer $(p=$ .003), affordability $(p=.002)$ and advantages $(p=.02)$ have a significant effect on the business-to-business relationship between SMEs and insurance providers. Statistically this means that these factors can determine the existence or non existence of a business-to-business relationship between SMEs and insurance providers.

Statistically, the null hypothesis is rejected and the alternative hypothesis is accepted. It is concluded that:

The level of training in the field of short term insurance and the factors influencing the purchase of insurance by SME managers or owners has an effect on their relationship with insurance brokers.

\subsection{Secondary Hypothesis}

H0: SMEs who have an insurance policy and have been approached by insurance broker do not have a business relationship with insurance providers;

H2: SMEs who have an insurance policy and have been approached by insurance broker have a business relationship with insurance providers. 
The type of insurance, having an insurance policy, approached by insurance broker and business-to-business relationship, all had high reliabilities, all Cronbach's $a=.8$. ANOVA (Analysis of variance) as well as multiple regression were used to test the statistical significance of the hypothesis.

Table 10: Anova Results Showing How Being Approached By An Insurance Broker And Having An Insurance Policy Affect The Business-To-Business Relationship Between Smes And Insurance Providers

\begin{tabular}{|c|c|c|c|c|c|c|}
\hline \multicolumn{2}{|r|}{ Model } & Sum of Squares & $\mathrm{df}$ & Mean Square & $\mathrm{F}$ & Sig. \\
\hline \multirow{3}{*}{1} & Regression & 1.947 & 2 & .974 & 7.219 & $.001^{\mathrm{a}}$ \\
\hline & Residual & 21.986 & 163 & .135 & & \\
\hline & Total & 23.934 & 165 & & & \\
\hline \multirow{3}{*}{2} & Regression & 5.265 & 12 & .439 & 3.596 & $.000^{\mathrm{b}}$ \\
\hline & Residual & 18.668 & 153 & .122 & & \\
\hline & Total & 23.934 & 165 & & & \\
\hline \multicolumn{7}{|c|}{ a. Predictors: (Constant), Approached by Broker, Have Insurance Policy } \\
\hline \multicolumn{7}{|c|}{$\begin{array}{l}\text { b. Predictors: (Constant), Approached by Broker, Have Insurance Policy, Employee Dishonesty, Personal liability, Other, Public } \\
\text { Liability, Buildings, Employee's Liability, Contents, Risk, Vehicle/fleetl, Electronic equipment, Stock \& Money }\end{array}$} \\
\hline
\end{tabular}

There are two models that were fitted into our multiple regression analysis. The first model, Model one included having an insurance policy and being approached by broker. These factors had an effect on business-to-business relationship between SMEs and insurance providers, $F(2.163)=7.23, p<.05$. Model two included the type of insurance held by SME owners/managers for their business and this was also found to be significant with a $p<.05$.

Table 11: Regression Analysis Showing How Being Approached By An Insurance Broker And Having An Insurance Policy Affect The Business-To-Business Relationship Between Smes And Insurance Providers

\begin{tabular}{|c|c|c|c|c|c|c|}
\hline & \multirow[t]{2}{*}{ Model } & \multicolumn{2}{|c|}{$\begin{array}{l}\text { Un-standardised } \\
\text { Coefficients }\end{array}$} & \multirow{2}{*}{$\begin{array}{c}\begin{array}{c}\text { Standardised } \\
\text { Coefficients }\end{array} \\
\text { Beta }\end{array}$} & \multirow[t]{2}{*}{$\mathrm{t}$} & \multirow[t]{2}{*}{ Sig. } \\
\hline & & $\mathrm{B}$ & Std. Error & & & \\
\hline \multirow{3}{*}{1} & (Constant) & .916 & .122 & & 7.508 & .000 \\
\hline & Have Insurance Policy & -.032 & .058 & -.041 & -.545 & .586 \\
\hline & Approached by Broker & .243 & .064 & .286 & 3.794 & .000 \\
\hline \multirow{13}{*}{2} & (Constant) & 1.028 & .427 & & 2.406 & .017 \\
\hline & Have Insurance Policy & -.053 & .106 & -.069 & -.504 & .615 \\
\hline & Approached by Broker & .169 & .065 & .200 & 2.595 & .010 \\
\hline & Vehicle/fleetl & .028 & .096 & .036 & .287 & .774 \\
\hline & Buildings & -.244 & .086 & -.283 & -2.840 & .005 \\
\hline & Contents & .118 & .106 & .131 & 1.106 & .271 \\
\hline & Electronic equipment, Stock \& Money & -.224 & .118 & -.259 & -1.901 & .059 \\
\hline & Public Liability & .011 & .099 & .011 & .116 & .908 \\
\hline & Personal liability & .133 & .079 & .159 & 1.692 & .093 \\
\hline & Employee's Liability & .285 & .108 & .273 & 2.631 & .009 \\
\hline & Employee Dishonesty & .051 & .172 & .023 & .298 & .766 \\
\hline & Risk & .158 & .092 & .192 & 1.715 & .088 \\
\hline & Other & -.291 & .128 & -.182 & -2.276 & .024 \\
\hline
\end{tabular}

It was further observed (refer to the table above) in the first model that being approached by an insurance broker is significant $(p=.000)$ in predicting the business relationship between SMEs and insurance providers. Whilst having an insurance policy ( $p>.05)$ is not necessarily a predictor of having a business relationship with insurance providers.

In model two, having an insurance policy that covers buildings, electronic equipment, stock \& money, personal liability, employees liability and other insurance policies were seen to be significant with $p$-values less than .05 . 
Fig 2: SMEs who have insurance policies, have a business relationship with insurance providers and have been approached by an insurance broker

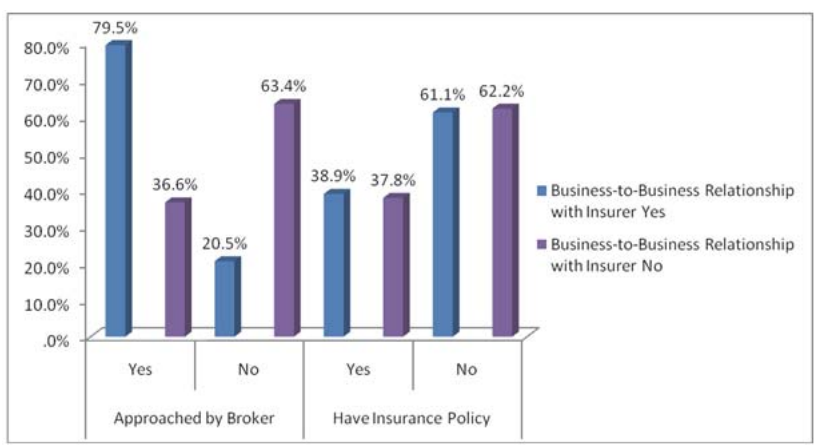

The graph illustrates that $79.5 \%$ of the respondents who agreed to having been approached by an insurance broker and $38.9 \%$ who agreed to have an insurance policy also agreed to having a business relationship with an insurance company. Of those who had not been approached by an insurance broker $20.5 \%$ said yes to having a business relationship with an insurance company, $61.1 \%$ respondents without an insurance policy had a business relationship with insurance providers.

The study shows that $62.2 \%$ of the respondents who did not have an insurance policy did not have a relationship with an insurance company, and $63.4 \%$ who were not approached by an insurance broker did not have a relationship with an insurance company. The results also illustrated that $36.6 \%$ of the SMEs who were approached by an insurance broker did not have a business relationship with an insurance company. Of those respondents who had insurance policies $37.8 \%$ did not have a relationship with an insurance company.

Hence, statistically we reject the null hypothesis and conclude that alternative hypothesis which states that:

SMEs who have an insurance policy and have been approached by insurance broker have a business relationship with insurance providers is accepted.

The primary and secondary null hypotheses were both rejected and the null hypotheses were accepted. The results illustrated that there were many factors that influenced the business-to-business relationship between SMEs and insurance providers. The main factors such as the brand name of insurer, affordability and advantages had a significant effect on the business-to-business relationship between SMEs and insurance providers. The results also highlighted that, there was a significant relationship between businesses that had been approached by insurance brokers and their having a business-to-business relationship with an insurance providers.

\section{Conclusions}

The main objective of the research was to determine which factors have the most influence on relationship building between SMEs and insurance providers. The conclusion reached through the results is that factors such as the reliability of an insurer, staff knowledge and brand name of the insurer have a great impact on the decision made by SME to build a relationship with insurance providers. Research revealed that the respondents who had been approached by an insurance broker, $79.5 \%$ of the SME owners/managers had a business relationship with an insurance provider. This helps to reach a conclusion that any form of interaction between SME owners/managers and insurance providers helps to facilitate a business relationship.

The results reveal that only $16.7 \%$ of SME owners/managers had any form of training on short term insurance and most of them (72.1\%) want to be trained in this field. The training of SME owners/managers is crucial for the relationship building process between SMEs and insurance providers. This shows that SME owners/managers had not been offered any form of training or informative workshops by insurance providers. Although, more than half (66\%) of SMEs had been approached by an insurance broker. This leads to the conclusion that SMEs are not aware of the different insurance products that are available to them in order to mitigate the risk they face. There is unpredictable weather phenomenon that is occurring around world. These adverse conditions can result in floods, fires and other natural disasters, because of these and many other disasters that can occur SME owners/managers need to be prepared. The South African government can put in place legislation that enforces SME owners/managers to have insurance policies that cover their 
employees and their assets. This is a way to ensure that SMEs are protected from any form of crisis that may result in their closure and resulting in the owners and their employees going to the job market and adding on to the list of the unemployed.

\section{Managerial Recommendations}

The study has shown that there are many factors that influence the business relationship between SMEs and insurance providers. It is recommended that insurance providers should increase their interaction with SMEs. They need to hold frequent workshops for SMEs where they can get a chance to inform them of their various product offerings. Insurance providers can hold research programmes twice a year, where they can be able to find out what sort of insurance cover they need to offer SMEs and at the costs that they can afford.

One of the major factors that influenced the relationship building process between SMEs and insurance providers is the reliability of the insurer (96\%). Insurance providers can use workshops, road shows and they can hold summits where they can invite SMEs. This will give them a chance to interact with their clients and create a platform where they can provide information concerning their premiums and pay outs when a claim has been made. Insurance providers need to build a relationship with SMEs and trust should be the foundation. They need to train their staff on how to deal with SME owners/managers, their products and payment plans as well as claims. This is all part of the relationship building process.

The study revealed that $72.1 \%$ of the SME owners/managers want to be trained on insurance. Insurance providers can therefore, hold frequent workshops and training sessions with SME owners/managers so that they can have an understanding of the type of insurance policy covers that their businesses need, the premiums and how insurance claims can work for them. Based on the number of SME owners/managers who have been trained, insurance providers are not holding needs analysis with their client (SMEs). It is required under the South Africa. Financial Advisory and Intermediary Services (FAIS) Act 37 of 2002 that they hold educational workshops, to enable them to get the needs of their clients and offer them products that suit their financial bracket. This is in breach of the requirements stipulated by this Act.

SME owners/managers expressed an interest in short term insurance by indicating their willingness to be trained in this field. There were $83.3 \%$ of SME managers/owners who had not received any form of training or workshops on insurance. This suggests that insurance providers are not complying with the code of conduct that is provided in the Financial Advisory and Intermediary Service Act of 2002. The government needs to ensure that insurance providers follow the law and if they fail to meet the requirements stiffer penalties need to be introduced. In other words, the government should amend the Act and introduce stiffer penalties to those who default. The government can also look into giving incentives to insurance providers so that they develop insurance products that suit the particular needs of the SME sector. This would result in a more stable and sustainable SME sector which will create jobs and help with the fight against poverty.

\section{References}

Aliber, M. 2002. South African Microinsurance Case Study. Geneva: International Labour Organisation.

African Development Bank and OECD Development Centre. 2005. African Economic Outlook. Available: http://www.oecd.org/ dev/publications [accessed: 1 April 2008];

Brink, A. \& Berndt, A. 2004. Customer Relationship Management and Customer Service. Lansdowne: Juta \& Co.Ltd;

Claro, D.P. 2004. Coordinating Business-to-Business Cross Border Supply Chains: The Case of the Organic Coffee Industry. Available: http://www.emaraldinsght.com [accessed: 5 March 2008];

Cooper, D.R. \& Schindler, P. 2003. Business Research Methods. $8^{\text {th }}$ edition. New York: McGraw-Hill;

Cronje, G. J.J., Du Toit, G.S. \& Motlatla, M.D.C. 2003. Introduction to Business Management. $5^{\text {th }}$ Edition. Cape Town: Oxford University Press;

Daniels, L. 1998. What drives the small-scale enterprise African entrepreneurship: Theory and reality. Gainesville Florida: University of Florida Press;

De Vos, A.S. 2002. Research at grass roots: for the social sciences and human services professions. Pretoria: Van Schaik;

Dumaine, B. 1993. Times Are Good? Create A Crisis. Fortune, Chicago, (127)13: 123-127;

European Commission Recommendation. 2003. Official Journal of the European Union. 124, p. 36 of 20 May 2003;

Elsubbaugh, S., Fields, R. \& Rose, M.B. 2004. Preparation for Crisis Management: A Proposed Model and Empirical Evidence. Journal of Contingencies and Crisis Management, (12)3: 112-127;

Field, A. 2009. Discovering Statistics Using Spss Third Edition. London: Sage Publications Ltd;

Finweek. 2012. Fragmented approach to assisting SME's is inefficient. Available: http://www.finweek.com/2012/11/13/fragmentedapproach-to-assisting-smes-is-inefficient/ [accessed: 15 May 2013]; 
Garson, D. Chi-square Tests: Statsnotes from North Carolina State University. Available: http://www.faculty.chass.ncsu.edu/garson/2009 [accessed: 10 November 2011];

Gregory, G., Harvive, C., \& Lee, H. 2002. Korean SMEs in the Wake of the Financial Crisis: Strategies, Constraints, and Performance in a Global Economy. Working Paper Series, University of Wollongong;

Independent Online (IOL) News. 2008. Flood havoc in KZN. Available: http://www.iol.co.za [accessed: 15 November 2012];

Investors Words. 2007. Available: www.investorswords.com [accessed: 20 March 2011];

Keats, B.W. and Bracker, J.S. 1988. Toward a theory of small firm performance: a conceptual model. American Journal of Small Business. Spring: 41-58;

KNC \& Associates. 2002. Access to Finance. Presentation to APDF Conference;

Leedy, P.D. \& Ormrod, J.E. 2001. Practical Research: Planning and Design. $7^{\text {th }}$ Edition. New York: Upper Saddle River, N.J: Pearson Prentice Hall;

Leedy, P.D. 2005. Practical Research: Planning and Design. New York: Prentice Hall;

Little, E. \& Marandi, E. 2003. Relationship Marketing Management. London: Thomson Learning;

Longenecker, J.G, Moore, C.W. \& Petty, J.W. 2003.Small Business Management: An Entrepreneurial Emphasis. Ohio: Thomson Southern-Western;

Longenecker, J.G. Moore, C.W. \& Petty, J.W. 2000. Small business Management: An Entrepreneurial Emphasis. London: SouthWestern College Publishing;

OECD. 2010. "Entrepreneurship and Migrants', Report by the OECD Working Party on SMEs and Entrepreneurship, OECD. Available: www.oecd.org/dataoecd/34/18/45068866.pdf [accessed: 15 May 2013]

Macgregor, D. 2012. Eastern Cape counts costs of floods. Times Live, October. Available: www.timeslive.co. za/thetimes/2012/10/25/estern-cape-counts-costs-of-floods [accessed: 15 May 2013];

Mahembe, E. 2011. Literature review on Small and Medium Enterprises' Access to Credit and Support in South Africa.Available: www.ncr.org.za/pdfs/Literature\%20Review\%20on\%20SME\%20Access\%20ro\%20Credit\%20in\%20South\%20AfricaFinal\%Report NCRDec\%201211.pdf [accessed: 15 May 2013]

Manning, A. 2002. Business Interruption and Claims - A Practical Guide. 2nd Edition. Camberwell: Manning's of Manning;

Manning, A. 2004. Strategic Management of Crises in Small and Medium Businesses. PhD thesis, Victoria University, Australia;

Megginson, W.L., Byrd, M.J., Scot C.R. \& Megginson, L.C. 1997.Small Business Management. Boston: McGraw-Hill Companies;

Ministry of Trade and Industry. 1994. Strategies for the development of an integrated policy and support program for Small, Medium and Micro enterprises in South Africa. A discussion paper. Government Publications;

Mitroff, I. 2000. Managing Crises Before They Happen. New York: AMACON;

Moore, C.W, Petty, J.W, Palich, L.E. \& Longenecker, J.G. \&. 2008. Managing Small Business: An Entrepreneurial Emphasis. Ohio: South-Western Cengage;

Mouton, J. 2001. How to succeed in your master's and doctoral studies: a South African guide and resource book. Pretoria: Van Schaik;

Mthimkhulu, V. 2008. New Deal In The Offering for SMMEs. Enterprise, May, pp 10-18;

Mutezo, A. T. 2005. Obstacles in the access to SMME finance: an empirical perspective on Tshwane. Unpublished master's thesis, University of South Africa, South Africa;

Ntsika. 2002. State of Small Business in South Africa: Annual Review. Enterprise Promotion Agency. Pretoria;

Rwigema, H. \& Venter, R. 2004. Advanced Entrepreneurship. Cape Town: Oxford University Press Southern Africa;

Ryals, L.J. 2006. Profitable Relationships with keys customers: How suppliers manage pricing and customer risk. Journal of Strategic Marketing, Vol.14 (2), 101-113;

SBA (Small Business Administration). 2004. What is a small business? Available: www.sba.gov/businessop/standards/smallbus.htm [accessed: on 06 May 2012];

Small Enterprise Development Agency (SEDA). 2008. SEDA - Who we are. Available: http://www.seda.org.za/content.asp [accessed: 27 April 2012];

Shepard, D.A., Douglas E.J. \& Shanley, M. 2000. Ignorance external shocks, and risk reduction strategies. Journal of business Venturing, Vol.15. 393-410;

Smits, S.J. \& Ezzat, N. 2003. Thinking the Unthinkable: Leadership's Role in Creating Behavioural Readiness for Crisis Management. Competitiveness Review, 13(1): 1-23;

South Africa. 1996. National Small Business Act number 102 of 1996. Pretoria: Government Printers;

South Africa. 1998. Short-Term Insurance Act of 1998. Pretoria: Government Printers;

South Africa. Financial Advisory and Intermediary Services Act 37 of 2002;

South African Broadcasting Cooperation (SABC) News. 2009. Cape Town hit by floods. Available: http://www.sabcnews.com [accessed: 06 January 2010];

South African Broadcasting Cooperation (SABC) News.2006.Southern Cape Flood damage estimated at R400million. Available: http://www.sabcnews.com [accessed: 31 March 2010];

Statistics South Africa (SSA). 2013. Quarterly Labour Force Survey: Quarter 4 (October To December), 2012 Press Statement.Available: http://www.statssa.gov.za/news_archive/press_statements/QLF-Q4-2012.pdf [accessed: 16 April 2013];

Strut, R.S.G. 1998. "Why Insurance", Captive Insurance Company Review. April 1998, pp8-11;

Taymaz, E. 2005. Are Small Firms Really Less Productive? Small Business Economics, Vol.25. pp 429-445;

Valsamakis, A.C., Vivian, R.W. \& Du Toit, G.S. 2005. Risk Management: Managing Enterprise Risks. $3^{\text {rd }}$ Edition. Sandton South Africa: 
Heinemann Publishers;

Van der Nest, D. 2004. The Impact of Black Economic Empowerment on the Management of Small Companies in South Africa. Unpublished Master's Dissertation. Rand Afrikaans University;

Wegner, T. 2003. Quantitative methods for marketing decisions. Cape Town: Juta;

Welman, J.C. \& Kruger, S.J. 2001. Research Methodology for Business and Administrative Sciences. Cape Town: Oxford University Press;

Zaayman, P. 2003. Financial Requirements of eCRM Solutions for the South African SME Sector. Published Master's dissertation. Rand Afrikaans University, South Africa;

Zikmud, W.G. 2003. Business Research Methods. $7^{\text {th }}$ edition. Australia: Thomson South-Western. 